
Tydskrif vir Taalaanleer

\title{
CONSTRAINTS EXPERIENCED BY EFL LITERATURE STUDENTS: A CASE STUDY FROM AN ALGERIAN UNIVERSITY
}

\author{
Mr T Bouazid (University of Mohamed Boudiaf, Msila, Algeria) \\ Prof CS le Roux (University of South Africa)*
}

This article investigates the perceptions and experiences of second language reading and comprehension of Arabic-speaking university students in TEFL (Teaching English as a Foreign Language) literature classes. In reflecting students' observations and experiences in a variety of classroom activities, the study attempts to uncover the constraints and challenges students experience and to suggest ways in which these difficulties could be overcome. The findings of the study reveal that lecturers have a significant role to play in helping students overcome barriers to understanding and interpreting literature. Recommendations for improving comprehension and enjoyment in L2 literature studies include the teaching and modelling of appropriate reading strategies that improve critical and analytical thinking skills; teaching and learning within a collaborative learning environment which fosters the development and exploration of ideas; and improving students' background knowledge relevant to the text being studied.

\section{Keywords}

EFL learners, reading competence, comprehension competence, schema theory

\section{INTRODUCTION}

Attempts to describe the actual process of reading vary greatly, with Goodman $(1967 ; 1988)$ commenting that reading is really a mystery, that nobody knows how reading works and that reading is in effect a psycholinguistic guessing game! Although these comments could be construed as cavalier, they perhaps point to the difficulty of defining a process so complex and at the same time so integral to modern human existence.

Proposed explanations of what reading entails are attempts to capture the core essence of the process. To illustrate, MacLeish (1968:43) proposed that reading firstly requires getting sounds from the printed page or, as Goodman (1998:11) puts it, matching sounds to letters, a process that is either oral (audible) or silent. Following this, meaning needs to be assigned to the sound and the information derived needs to be interpreted appropriately (Grabe \& Stoller, 2002:9). This process of interpreting information to facilitate comprehension is multidimensional. For example, Harmer (2001:200) states that a reader uses a variety of clues to understand what the writer is implying, thereby moving beyond the literal meaning of the words to the contextually and conceptually implied meaning. Chastain (1988:228) suggests that the reading process entails active, cognitive interaction between mind and text in order to interpret and comprehend the text. During the writing process, the writer tries to activate 
background and linguistic knowledge to create meaning: the reader's task is to activate background and linguistic knowledge to recreate the writer's intended meaning. This process is critical to studying and understanding literature.

It would follow from the preceding that the reading process comprises (1) learning to interpret symbols and pronounce words (MacLeish, 1968; Goodman, 1998:11); (2) identifying words and understanding their meaning (Chastain, 1988; Dechant, 1991; Grabe \& Stoller, 2002:9; Grabe, 1991:392); and (3) learning to bring meaning to a text in order to derive meaning from it (Foertsch, 1998; Harmer, 2001; Rumelhart, 1977; Smith, 1985; Wallace, 2003; Weaver, 2002). Grabe (1991:396) suggests a concomitant components approach to reading and distinguishes six skills and knowledge areas, namely automatic recognition skills; vocabulary and structural knowledge; formal discourse structure knowledge; content/world background knowledge; synthesis and evaluation skills/strategies; and meta-cognitive knowledge and skills monitoring.

It is evident that, when a person reads, she or he engages in a complex set of emotional, symbolic, moral, intellectual and social processes and activities (Lye, 2003). Engagement in literary studies presupposes adequate reading skills, which Urquhart and Weir (1998:37) describe at the most basic level as recognising letters and words and automatically prompting the meaning of words. Grabe and Stoller (2002:56), Anderson (2007:5-7) and Wallace $(2003: 3-4 ; 7)$ emphasise that the reading process extends beyond these basic mechanistic and cognitive skills and calls for interpretation, comprehension and critique in a search for meaning. When students engage in literary studies it is assumed that they are equipped not only with adequate literacy or reading skills, but also with the ability to interpret and comprehend what is read. Support for this tenet is provided by Isenberg (1990) and Torell (2001) who confirm that literary competence cannot be reduced to internalised literary conventions and that literary competence includes more than a form of information processing or cognitive ability - hinting at comprehension being an integrated, holistic process, as suggested by Harmer (2001), Grabe (1999) and others.

Recent studies (Afzali \& Tahririan, 2007; Grenfell \& Erler, 2007; Zengier \& Shepherd, 2003) have indicated that many university students find literary studies extremely challenging and unrewarding. It appears that they struggle to fully understand or appreciate what they read, ostensibly because they have not yet learnt or developed strategies that support or promote reading and comprehension. This appears to be especially true when studying literature in a foreign language (L2). Chun and Plass (1997:61) concede that there are significant challenges related to teaching $\mathrm{L} 2$ reading and comprehension.

The primary researcher and author, who teaches British and American Literature to undergraduate students at university level in Algeria, has consistently encountered difficulties teaching English literature to Arabic-speaking students. The students generally appear to lack the ability to read, proficiently comprehend, or appreciate the literary works studied in the literature studies programme. The research reported on in this article consequently comprised qualitatively establishing, examining and analysing students' experiences with L2 reading and comprehension and the challenges and constraints encountered. At the same time, an attempt was made to establish which learning strategies students used when attempting their reading assignments. The purpose of this research was to inform the pedagogy of teaching literature studies in a TEFL context. 


\section{THEORETICAL FRAMEWORK}

Wallace (1986:70) suggests that the basic process of learning to read is acquired only once. Learning to read a second language is an extension of that literacy. However, specific reading strategies may vary from language to language and when literary competence is sought in L2, because languages vary in their meaning-making conventions, the reading (and writing) skills that need to be mastered invariably differ from those required for L1. These variations can have critical implications for L2 reading and comprehension and also for teaching L2.

Furthermore, unlike L1 reading, L2 reading involves two languages. The dual language involvement implies continual interactions between the two languages, as well as continual adjustments in accommodating the disparate demands each language imposes. L2 learning can be described as being cross-linguistic and inherently more complex than L1 learning (Koda, 2007:1).

Kitao and Kitao (1989:10) add that, apart from the cross-linguistic issue that complicates the process of L2 reading and comprehension, the differences between the socio-cultural context of the reader and the context of the L2 text further complicate interpretation and comprehension. Since meaning is socially constructed and text is understood and interpreted within the framework of existing knowledge (Wallace, 2003:9), what the reader knows is as important as what is on the page.

This notion that reading or language comprehension is linked with a reader's prior knowledge has been formalised as schema theory (Bartlett, 1932). According to schema theory, reading comprehension is an interactive process between the text and the reader's background knowledge (Adams \& Collins, 1979; Rumelhart, 1980; Wallace, 2003). A semantic bridge based on the reader's schema stored in the memory is formed between the meanings of the words and their interpretation. It is this interaction of new information with old knowledge that is described as 'comprehension' (Anderson \& Pearson, 2002:255). Reading comprehension thus depends on the reader being able to relate information from the text to pre-existing background knowledge (Grabe, 2004:50). Since schemata are cognitively constructed within specific social or cultural contexts, this has specific implications for L2 reading and comprehension where the text that needs to be comprehended relates to a culture other than that of L1 (Wallace, 2003:22, 57). Readers comprehend texts better when the texts are culturally familiar to the reader and consequently students tend to interpret L2 texts according to the most similar schema that they have (Grabe, 2004:50; Kitao \& Kitao, 1989:10-11) - which would be L1 schema. Consequently the inferences drawn when reading L2 texts tend to relate to established L1 schema, rather than that of the culture of L2.

Research into L2 reading strategies commenced in the 1970s with the seminal work of Rubin (1975) and Stern (1975) who suggested that a model for a good language learner could be constructed by looking at the specific strategies used by successful L2 students. Interest in such research appears to have been renewed recently (Takeuchi, 2003; Chamot, 2005; Cooper, 2002; Koda, 2007). Chamot (2005:112-130) emphasises the significance of determining and studying students' learning strategies in L2 contexts since this provides insight into the meta-cognitive, cognitive, social and affective processes involved in language learning and reading comprehension and offers teachers the opportunity to improve the pedagogy of teaching in L2 contexts. 
Researching students' learning strategies relies extensively on collecting data through various self-report procedures (Chamot, 2005). Although self-report is always subject to error, no better way has yet been devised to identify students' mental processes and techniques for completing a learning task. Grenfell and Harris (1999:54) comment that 'it is not easy to get inside the "black box" of the human brain and find out what is going on there. We work with what we can get, which despite the limitations, provides food for thought.' While most of the learning and comprehension strategies cannot be observed, some are associated with observable behaviour (Chamot, 2005:113) which justifies researcher observation as a data collection strategy when conducting research into L2 reading and comprehension processes.

From the foregoing it is evident that engagement in literature studies requires critical engagement with the text and presumes the construction of meaning and comprehension while acknowledging that comprehension depends on the extent to which new information can be linked to existing schema. Within the context of the research undertaken, it was argued that what students say about their experiences when engaging in literary studies should provide insight into the constraints and obstacles experienced in their studies and provide insight into the reading and comprehension processes and strategies employed.

\section{RESEARCH DESIGN}

A qualitative research approach was selected to determine, examine and analyse the reading experiences of L2 literature studies students to identify the barriers and challenges experienced in reading and comprehending L2 texts. A qualitative approach was chosen since it, by nature, is exploratory, interpretative and descriptive and is an attempt to understand multiple realities (Babbie \& Mouton, 2001:270-271; Leedy \& Ormrod, 2001:102). Qualitative studies furthermore have the potential to provide rich, detailed data (Carr, 2008:716). The research findings would be used to establish appropriate strategies to support L2 students in their reading, interpretation and comprehension of foreign language literature.

\section{RESEARCH CONTEXT, POPULATION AND SAMPLING PROCEDURES}

The research focused on examining the perceptions, thoughts and experiences of second-year English literature students with regard to their studies of a compulsory English Literature module in the four-year BA Didactics TEFL programme at a residential university in Algeria. All students who register for this module have passed their first year in English Studies. However, this module is their first encounter with English Literature. The literature studies course is divided into eight semesters, spread over two years. The tuition provides for four British and four American literature studies modules, plus a choice between a British or an American literature seminar course in the final year.

The time allotted to the literature studies module is $1 \mathrm{hr} 20$ min per week. The second-year British Literature syllabus covers a general introduction to literature, literary terms and the various literary genres. The British literature programme covers the beginnings of English literature (450-1066); the Middle Period (1066-1500); literature from the accession of James 1 to the Restoration (1600 to1660); the development of the sonnet form; lyrical ballads; and the works of Chaucer, Shakespeare, Dryden and Alexander Pope. Other authors and their works included in the syllabus are Bacon, Milton, Bunyan, Swift, Defoe, Fielding, Goldsmith and 
Sheridan. Apart from attending and participating in the lectures, students are also required to prepare project work on these authors and the periods covered.

Three hundred students registered for the module and the class was divided into two groups, each comprising 150 students. The observation and interaction component of the research involved both groups of students while the analysis of learning log entries was restricted to a sample taken from the registered student cohort. Fifty students whose learning logs would be collected for analysis were randomly selected from the enrolment list. Random sampling reduced the likelihood of bias, since research participants were chosen entirely by chance and each student on the list had an equal chance of being selected (Birchall, 2009).

\section{MEASURES TO ENSURE RESEARCH VALIDITY AND RELIABILITY}

To ensure validity and reliability, the research process was designed and conducted in accordance with established research principles pertaining to choice of appropriate research approach, data collection instruments and data analysis ( $c f$ Birchall, 2009; Cresswell, 2003; Cohen, Manion \& Morrison, 2002). Research bias was eliminated by using simple random selection methods in determining the research sample (Birchall, 2009).

Ethical principles were followed. Students were informed of the researchers' intention to undertake the research. The purpose of the research was explained and students were asked to indicate whether they were willing to engage in the research and, if they objected, they were assured that their contributions to the class interaction and discussions would not be taken into account. Furthermore, they would not be included in the sample from which learning logs would be collected for analysis. Participants were informed that the research findings would be used to improve the teaching of L2 literature studies and that the results would be reported in academic forums. Students were assured of anonymity. None of the students indicated reluctance to be involved in the research.

The designated data-collection tools were used systematically, consistently and reflectively. Multiple methods of data collection were used - observations, discussions, unstructured interviews and text analysis - to ensure richness, comprehensiveness and depth of the findings. The use of multiple data collection methods increases the validity of the research findings and the conclusions drawn. This, in turn, contributes to the rigour and soundness of the study.

To reach construct validity, the researchers first undertook a comprehensive review of the literature to establish the theoretical foundation of the study and to ensure that, in the research process, the meaning attached to the concepts was consistent. As noted previously, qualitative studies are primarily descriptive, explanatory and exploratory, and the literature review provides a rich background against which the research results can be analysed and interpreted. Literature reviews also stimulate theoretical sensitivity to concepts and to relationships between concepts (Cresswell, 2003:32). Concepts that repeatedly come up in literature reviews could have particular significance and draw the researchers' attention to details and ideas that need to be probed during the research process.

During the analysis and interpretation of the data, the deductions were constantly evaluated against the background of the literature. The researchers tried to establish a holistic view of 
the different causes and factors that impede students' ability to read and comprehend L2 literature.

\section{RESEARCH PROCESS AND DATA COLLECTION}

The study was undertaken between January and June 2009. Data were obtained in the classroom setting through participant observation, unstructured interviews and interaction with students. A sample of students' written responses to a specific literature studies assignment entered in their learning logs served as an additional data source. The researchers believed that the emerging data could serve to clarify and provide insight into the following:

- how students experience literature studies

- $\quad$ how students engage with literature and approach assigned tasks

- $\quad$ how students interact with fellow students and the lecturer in the classroom

- factors that constrain students' reading, interpretation and comprehension of literature

\section{PARTICIPANT OBSERVATION}

As part of regular teaching sessions, the primary researcher assigned reading tasks and observed how learners approached these assignments. Participant observation is integral to understanding the breadth and complexities of research participants' experiences. Factors that are significant for a thorough understanding of the research problem can be uncovered through observation. Participant observation also helps one understand and interpret data obtained through other methods, because it provides a context for understanding that data. Students' responses to the learning activities were noted and written up as descriptive narratives in the researcher's journal for analysis and interpretation.

\section{INFORMAL DISCUSSIONS, INTERACTIONS AND UNSTRUCTURED INTERVIEWS}

The informal discussions and unstructured interviews conducted with students focused primarily on asking them to elaborate on their experiences related to reading and interpreting literature studies text. Students' comments were noted in the researcher's journal for analysis and reflection.

\section{ANALYSIS OF LEARNING LOG ENTRIES}

An in-depth analysis of students' written reports on their appraisal and reflections of a specific reading task formed a third component of the data-collection process. For this task, the researcher chose Chaucer's The Physician's Tale, (cf Bookwolf, 2010) which is one of the prescribed readings in the module. The students were asked to read the tale, reflect on and report their thoughts and experiences while engaging with the material, and then provide an appraisal of the literary meaning of the text. Students were asked to write up their comments in detail in their learning logs. They were given one month to complete the Chaucer reading. The students' learning logs were collected and the logs of the research sample were removed and coded from 01 to 50 to ensure anonymity. 
The assumption was that establishing what students say about their engagement with the texts would provide insight into the factors that influence their engagement with the literature; the strategies used when interacting with the text; and the issues that determine their comprehension competence.

\section{DATA ANALYSIS}

After the data had been collected, it was studied and encoded according to units of meaning. The encoded responses were collated and grouped according to themes that arose from the analysis. The themes were particularly consistent across all data sources. Matrices of the categories were created and 'frequency of events' or 'frequency of comments' tables were drawn up for each theme.

\section{RESEARCH FINDINGS}

The findings in relation to the conditions under which students study, how students engaged with their tuition material, and students' interaction with others in the learning environment, are discussed below.

\section{OBSERVATIONS}

When first confronted with new reading assignments, most students appeared rather apprehensive about tackling the task. Although students have been encouraged to first skim read a new piece of literature and follow this with a more focused reading, the initial response to new material tended to be tentative. However, once students settled down to the task they seemed to gain confidence and engage more purposively with the reading assignment, making notes and underlining words or phrases. Dictionaries were used to look up unfamiliar words. Some students briefly chatted with others seated close by - ostensibly discussing the task. However, the majority tended to work on their own with little interaction with others or the lecturer. It was noticeable that students appeared to be content with having 'read the words' thereby completing the task in their view.

\section{INFORMAL INTERACTION, DISCUSSIONS AND UNSTRUCTURED INTERVIEWS}

The classroom atmosphere was generally relaxed and conducive to interaction between students and the lecturer, and between students and other students. The researcher encouraged the students - as a class, in groups and individually - to share their opinions about their reading experiences and the strategies they use when dealing with a reading assignment. From these discussions, students' perceptions of, and thoughts regarding literature studies were made evident.

\section{- PERCEPTIONS OF LITERATURE STUDIES}

Students reported that they find reading poetry and drama extremely difficult. The explanations were that poetry is very personal, symbolic, full of imagery and difficult words and has a deep and hidden meaning that they are unable to probe. Poetry invariably contains images that students cannot conceptualise since they lack knowledge of the context and circumstances required to interpret or comprehend the meaning. Students agreed that they find reading and interpreting fiction - short stories, tales and novellas - much easier than plays and poetry. However, the use of imagery and the idiom of the vernacular in the literature complicate interpretation and comprehension. 


\section{- READING FOR COMPREHENSION}

During the course of the lecture session, the lecturer would at times instigate a classroom discussion of unfamiliar words, concepts, metaphors or the meaning of the text as a whole. Some students participated in the discussions - albeit cautiously - but their comments and contributions were indeterminate and most were unable to meaningfully articulate their thoughts. Volunteering opinions or explanations was uncommon, and those who did risk making comments generally paraphrased the sections without providing much depth or evidence of having captured the essence of the text. Students were able to read the words, but lacked the skill to establish or assign meaning. Students seemed to be aware that to grasp the deeper meaning of texts, critical engagement is necessary, but were reluctant to risk opinions or explore ideas or read beyond the immediate and the obvious.

\section{- $\quad$ SCHEMA}

Students seemed to lack knowledge of the context or culture within which the text had been framed - regardless of whether this was in their studies of American or British literature. A lack of understanding of the historical context, cultural practices, social conventions and idiomatic language used decidedly constrained students' ability to comprehend the literature being studied. It appeared that students' general lack of vocabulary, language proficiency and relevant contextual background constrained their ability to read, interpret or comprehend texts.

\section{LEARNING LOG ENTRIES}

Students were assigned a reading task - Chaucer's The Physician's Tale - and were asked to detail their observations and thoughts on the assigned reading task in their learning logs. A measure of insight into the respondents' reading experiences, reading strategies and reading skills was obtained from a study of the entries. In general, students' comments were vague. They commented that they tried to understand the prescribed reading, but found it 'hard' or 'difficult' - without explaining why. If students commented that they had enjoyed or had not enjoyed the tale, they did not elaborate on their experience. The entries generally lacked depth and clarity and were somewhat disappointing. However, nine respondents provided reflections that were more specific and made observations and comments not mentioned by other respondents.

With regard to reading strategies used, students mentioned that by reading and rereading the text, they had managed to grasp the main gist of the tale. Some students mentioned that a dictionary was used to find the meaning of words, but none mentioned the fact that some of the words were difficult to find since some modern dictionaries do not cover old English (which was the case in The Physician's Tale).

The entries which were identified as providing more insightful comments and perspectives were the following:

1. I skimmed the poem but I did not understand anything because the language is old and archaic and the teacher did not give us a glossary of literary terms.

2. I read the text and I could guess some of the exposed themes. I used my prior knowledge about Chaucer's social life and the era he lived in and that could orient me somehow. 
3. I read the poem twice and as it is too long and written in Middle English I could not get the gist of it. I lack the technique of how to summarize the poem. I did outline and write in the margin, but that did not prove efficient [helpful].

4. I really find reading literature difficult because I feel the need to use a dictionary where I sometimes find difficulties in explaining difficult words I need to read behind the lines. In fact, reading literature demands a present wit, a fresh memory and a lot of speculation.

5. I think reading a long poem in old English is taking risks but later on when I started to understand some parts of it I felt stimulated to read on. At the end I could understand the main themes and that was very positive.

6. During my first reading I was stimulated by the musicality of the poem and its heroic couplets that let me read on without stopping. I focussed on the form and lost the meaning. I believe that to be able to understand the poem, a reader should read it silently for many times; should take notes and use the dictionary.

7. I found it difficult to read a long poem alone. I believe it could be better if it is read out collaboratively for sharing experiences, exchanging ideas. Discussing themes is of paramount importance.

8. I read the poem many times but I did not wholly understand it. But when in the class, and with the help of the teacher, I understood it quickly. I believe, knowing about strategic reading, the way poems are to be analysed, the most important ideas to sort out and the way a narrative piece hangs together, is a necessity to know.

9. I found the story quite interesting but lengthy. It took me some two hours to finish reading it. And though I did not wholly understand it, it pleased me and I felt very sympathetic and siding with the innocent girl and I pitied and envied both Virginia and Virginius. Through my reading, I realized how important is to know how to read, what to mark, when to pause and reflect, how to take notes and annotate the important elements and finally how to paraphrase and write a brief summary of every chunk in the story. In fact, reading well requires a strategy which will be reflected later on in the good writing.

The following critical issues emerged from students' comments:

- $\quad$ students need to be familiar with the language conventions and style relevant to the context to interpret and comprehend the text

- $\quad$ students understand that reading for comprehension depends on having acquired the necessary reading and interpretation skills and strategies

- $\quad$ students believe they lack the necessary reading skills and strategies to help them approach their literature studies effectively

- $\quad$ students are aware that comprehension requires in-depth understanding of the language, idiomatic conventions and cultural context

- when students experience a sense of accomplishment they are motivated to persevere

- $\quad$ students acknowledge that cooperative learning could contribute to and facilitate understanding and comprehension 
An analysis of the researcher's observations of student engagement and interaction in the classroom, unstructured interviews with students and learning log entries provided insight into students' experiences of engaging in L2 literature studies. A consolidation of the research findings indicated that several factors influence students' ability to engage with their literature assignments. These are discussed below.

\section{DISCUSSION}

The themes that emerged from the analysis of the data related to students' individual reactions, perceptions and experiences in relation to literature studies; the reading strategies that were used; interaction and engagement with others; and the factors that inhibit or aid reading with comprehension. These categories linked directly with the envisaged purpose of the research.

\section{STUDENTS' EXPERIENCE OF THEIR LITERATURE STUDIES}

Literature studies are commonly perceived as difficult and requiring considerable effort. As a result, assignments are generally approached with apprehension and a measure of anxiety. Students lack the confidence to participate in discussions, to share their ideas or air their opinions and, consequently, they remain passive and rely on others - generally the lecturer to provide direction. On the positive side, some students commented that once they understood the main themes of the text, they gained confidence and this led to being able to enjoy reading - both for its entertainment value and intellectual and emotional enrichment ( $c f$ Kringelbach, Vuust \& Geake, 2008).

\section{READING STRATEGIES}

There seems to be general consensus among students that the best way to engage with the literature is to skim read ( $c f$ student comment 6 ) and then read the text repeatedly until some measure of understanding is reached. Bachman and Cohen (1998:102) and Flowerdew and Peacock (2001:375) indicate that skimming allows readers to read for general understanding and this could be complemented by providing incremental evaluation activities (Erten \& Razi, 2009:63).

Dictionaries and glossaries are useful tools to help clarify unfamiliar words and terms, but they do have limitations - for example archaic words seldom appear in modern dictionaries. Students realise that they need to actively engage with the text in order to interpret it - to seek inferred meaning (reading between the lines) and speculate about meaning - if they are to ultimately comprehend what they have read. Students believe they lack the required strategies to engage meaningfully with text. This issue becomes clearer when the constraints mentioned by the students are discussed in detail.

\section{INTERACTION}

Because of students' general lack of self-confidence, they prefer to interact with the texts individually and engage in silent reading. So doing, they form their own opinions and, because these are not shared with others, they do not expose their ideas (or themselves) to discussion or criticism. This is the safe option - although not necessarily the best way to learn or manage their studies. Some students indicated that collaborative learning, class discussions and exchanging ideas would be a worthwhile way of interacting with their study material and improving their understanding of the texts. 


\section{CONSTRAINTS AND OPPORTUNITIES}

A summary of challenges experienced by students indicates the following:

- An inability to make sense of the texts because of unfamiliarity with the language, its idiom, and the cultural or ideological context within which the literature was written

- An inability to meaningfully engage with texts in a way that will enhance comprehension

- An inability to apply prior learning or make associations between the text at hand and previous studies

- An inability to move beyond a superficial interpretation and the obvious to reflection and an appreciation for deeper meaning

- Lack of the confidence needed to raise opinions or viewpoints and to explore alternative interpretations

- Not knowing how to approach literature studies and not knowing how to read strategically (e.g. make summaries, paraphrase, analyse texts and interrogate text for deeper meaning)

A number of proposals that are based on the conclusions are presented for the improvement of students' ability to make sense of, and ultimately enjoy, literature studies.

\section{RECOMMENDATIONS}

To improve students' enjoyment of and confidence and competence in their literature studies, it is necessary to deal with or reduce the impact of each of the constraining factors. However, each of these factors is multidimensional; consequently, a holistic approach needs to be adopted to solve the problem.

\section{ENGAGEMENT WITH LITERATURE STUDIES}

\section{- CREATE A TEACHING-LEARNING ENVIRONMENT THAT SUPPORTS} COOPERATIVE LEARNING

Reciprocal learning and teaching (an interactive, co-constructive or cooperative learning environment) is conducive to building comprehension (Karakas, 2002:189). Structured cooperative or collaborative learning situations in which groups are provided with guidelines regarding the task and what should be achieved at the end of the session have the potential to engage students more deeply in their studies and enhance critical thinking through fostering discussion and exploratory thinking, and clarifying and critiquing ideas. A condition for successful collaborative learning is to structure groups in such a way that the group members contribute complementary skills and knowledge (Dillenbourg, 1999:5; 2002). Building confidence in the context of smaller groups first could be a step towards engaging students to become involved in larger groups and general class discussions and debates.

Another factor that could contribute to creating a discursive environment would be for students to come to class adequately prepared and having read the texts prior to their being discussed in class. Students should see themselves as being accountable for their own progress and success and as being obliged to make an effort in this.

- USE TEACHING AND LEARNING APPROACHES THAT FOSTER CRITICAL READING AND THINKING

To promote reading comprehension, students should be provided with opportunities, and 
should be challenged to read and think critically. Critical thinking implies that a reader is actively and constructively engaged in the process of focused reading, which means that the reader is continually negotiating what he or she knows with what he or she is trying to understand. To appreciate and understand the literature being studied, students need to be able to discover information and ideas within the text and make inferences - something that can only be achieved through active, reflective and analytical reading (Riecken \& Miller, 1990:61).

Critical thinking involves evaluating information and ideas and reflecting on the validity of what has been read in the light of prior knowledge and an understanding of the world. To help learners become critical thinkers, it is essential that they come to value their own thinking as the basis of their decision-making and problem-solving initiatives. In this process they need to compare their thinking and their interpretations with peers, and to revise or reject parts of their own and other people's interpretations, reasoning or analysis - which is best accomplished in a cooperative learning environment.

To get students to engage critically with the literature being studied, Wilson (1988) advocates using strategies and techniques such as the following:

○ formulate questions to which students must respond prior to, during, and after reading

0 require students to respond to the text in terms of their own values and to contrast this with responding to the text from its cultural specific schemata

$\circ$ anticipate events or outcomes and recognise when and how reader expectations were roused and fulfilled

o respond to texts through a variety of writing activities that ask readers to go beyond what they have read and to experience the text personally

\section{- MODEL AND TEACH READING AND TEXT ANALYSIS SKILLS AND STRATEGIES}

Williams and Moran (1989:223) draw a distinction between a skill and a strategy: a skill is an automated ability which operates largely subconsciously; a strategy is a conscious procedure carried out with the purpose of solving a problem. Ambruster, Lehr and Osborn's research (2001:53) indicates that

... explicit teaching techniques are particularly effective for comprehension strategy instruction. In explicit instruction, teachers tell readers why and when they should use strategies, what strategies to use, and how to apply them. The steps of explicit instruction typically include direct explanation, teacher modelling ('thinking aloud'), guided practice, and application.

There is a definite need for direct guidance from lecturers on ways to approach reading tasks and assignments. Lecturers should discuss which strategies to use with each literary genre; how to paraphrase, write a summary and read notes. Lecturers should explain the strategy used, including both the procedure and the purpose of the strategy. By thinking aloud, lecturers could demonstrate how to go about the process of reflecting on one's own cognitive processes and to be aware of the processes engaged in while reading. Building on this, peer learning can be facilitated through talking amongst themselves - a process that deepens and refines understanding (Frey, 2006:3-6).

Chastain (1988:239) proposes post-reading activities to help readers clarify ambiguities and uncertainties where the focus is on the meaning and not on the grammatical or lexical aspects of the text. Ur (1996:55) points out that summaries can be used as a post-reading activity and 
that this particular activity could be conducted in the mother tongue.

A critical reader needs to develop his or her own strategy, which derives partly from his or her own skill, experience, talent or mental ability, but which benefits greatly from being modelled on the processes used by a skilled and experienced reader - such as the lecturer. Specific tasks that can be set during the reading process could include

o verifying whether students have understood the text by asking them to briefly paraphrase what they have read. Gaps in summaries could be filled through discussion and thinking aloud.

- making educated guesses or deducing the meaning of difficult words as they appear in the context by using various 'word attack' strategies

$\circ$ using reading checklists that encourage students to reflect on their reading experiences

Ultimately, students need to take responsibility for their learning and to become increasingly independent of assistance. In short, lecturers should model and share their own cognitive skills and strategies with the intention of handing this responsibility over to the students so that they can in due course apply the relevant strategies independently (Pearson \& Fielding, 1991:848-849).

\section{- PROVIDE BACKGROUND KNOWLEDGE RELEVANT TO THE LITERARY TEXT}

Reading comprehension requires interaction between the text and the reader's schema (Adams \& Collins, 1979; Rumelhart, 1980; Wallace, 2003). Text is written, and read, in a particular socio-cultural and historical context in which particular conventions and ideologies hold sway. If the reader is unable to link what is read to the appropriate schema, miscomprehension or non-comprehension could arise. One of the most obvious reasons why L2 students struggle to comprehend foreign texts, is because the required content schema may fail to exist since it is not part of a particular reader's cultural background (Carrell \& Eisterhold, 1983:560). Ultimately, a literature student needs to be able to make connections which are not explicitly outlined in the text and can only be acquired from his schematic knowledge. Harmer (2001:99), Nuttall (2000:8) and Wallace (2001:25) contend that only after the appropriate schema is activated, can the reader truly comprehend. Until this happens, the text is merely made to fit into what is already known and familiar to the reader.

A significant amount of evidence supports the view that the activation of background knowledge will lead to improved comprehension. Carrell and Eisterhold (1983:566-567) suggest practical strategies that lecturers could implement to provide the required background knowledge. These include:

- Provide students with initial readings that explain the specific context (e.g. culture, historical period, values, religion) of the literary work so that, when confronted with the text, students do not approach it 'cold'.

- Make use of narrow reading - reading that is confined to a single topic - so that students can become familiar with the vocabulary of the topic.

- Draw on the literary texts of a single author so that students have time to adjust to an author's style, expression and vocabulary. 


\section{CONCLUSION}

The research undertaken revealed that students who engage in foreign language literature studies encounter a variety of problems that compromise their comprehension and enjoyment of literary works. This research attempted to identify specific constraints and to recommend ways in which these barriers can be overcome. The primary constraints that were identified included: a lack of confidence to engage in cooperative learning experiences that could support reading comprehension; a need for constructive lecturer intervention and guidance related to strategies for reading for comprehension; the need for critical reading and comprehension strategies to be modelled to enable students to develop and apply these skills independently; and inadequate background knowledge to support interpretation and comprehension of the literary texts. Practical strategies and guidelines to overcome these constraints are suggested. It is the expectation that the implementation of the recommended strategies could lead to increased enjoyment of literary studies and improved comprehension of literary works in L2 learning environments.

\section{REFERENCES}

ADAMS, MJ \& A COLLINS. 1979. A schema-theoretic view of reading. In Freedle, RO (Ed), New directions in discourse processing. Norward: Ablex Publishing. 1-22.

AFZALI, K \& MH TAHRIRIAN 2007. Strategic needs of ESL students in developing their literary competence. The Asian ESP Journal, 3(1):4.

AMBRUSTER, BB, F LEHR \& J OSBORNE. 2001. Put reading first: The research building blocks for teaching children to read - kindergarten through grade 3. Washington: National Institute for Literacy.

ANDERSON, NJ. 2007. The role of metacognition in second language teaching and learning. In Kerka, S [Ed], What works? Study skills. Columbus: Ohio State University.

ANDERSON, RC \& PD PEARSON. 2002. A schema-theoretic view of basic processes in reading comprehension. In Pearson, PD [Ed], Handbook of reading research. Mahwah: Lawrence Erlbaum.

BABBIE, E \& J MOUTON. 2001. The practice of social research. Cape Town: Oxford University Press.

BACHMAN, LF \& AD COHEN. 1998. Interfaces between second language acquisition and language testing research. Cambridge: Cambridge University Press.

BARTLETT, FC. 1932. Remembering: A study in experimental and social psychology. Cambridge: Cambridge University Press.

BEDIR, H. 1992. Cultural significance in foreign language learning and teaching with special emphasis on reading comprehension through cultural schema. Unpublished MA thesis. Adana: Cukorova University.

BIRCHALL, J. 2009. Sampling and samples [Online]. Available: http://www.marketresearchworld.net/index.php?option=com_content\&task=view\&id=2 $3 \&$ Itemid $=1 \&$ limit $=1 \&$ limitstart $=0$ [2009, 22 January $]$. 
BOOKWOLF. 2010. Summary: The Physician's Tale [Online]. Available: http://www.bookwolf.com/Free_Booknotes/Canterbury_Tales_by_Geoffrey_C/Physicia n_s_Tale-Canterbury_Ta/physician_s_tale-canterbury_ta.html [2010, 21 January].

CARR, LT. 2008. The strengths and weaknesses of quantitative and qualitative research. Journal of Advanced Nursing, 20[4]:716-721.

CARRELL, P \& JC EISTERHOLD. 1983. Schema theory and ESL reading pedagogy. TESOL, 17(4):577-573.

CHAMOT, AU. 2005. Language learning strategy instruction: Current issues and research. Annual Review of Applied Linguistics, 25:112-130.

CHASTAIN, K. 1988. Developing second language skills: Theory and practice. Orlando: Harcourt Brace Jovanovich.

CHUN, DM \& JL PLASS. 1997. Research on text comprehension in multimedia environments. Language Learning \& Technology, 1[1]:60-81.

COHEN, L, L MANION \& L MORRISON. 2002. Research methods in Education. New York: Routledge.

COOPER, T. 2002. Challenging psychological issues. Milton Keynes: The Open University.

CRESSWELL, JW. 2003. Advanced mixed methods research design. In Tashakkori A \& C Teddlie [Ed], Handbook of mixed method in social and behaviour research. Thousand Oaks: Sage. 209-240.

DECHANT, E. 1991. Understanding and teaching reading: An interactive model. New York: Lawrence Erlbaum.

DILLENBOURG, P. 1999. What do you mean by collaborative learning? In Dillenbourg P [Ed], Collaborative learning: Cognitive and computational approaches. 1-19.

DILLENBOURG, P. 2002. The risk of blending collaborative learning with instructional design [Online]. Available:

http://hal.archives-ouvertes.fr/docs/00/19/02/30/PDF/Dillenbourg-Pierre-2002.pdf [2010, 26 October].

ERTEN, RH \& S RAZI. 2009. The effects of cultural familiarity on reading comprehension. Reading in a foreign language, 21(1):60-77.

FLOWERDEW, J \& M PEACOCK. 2001. Research perspectives on English for Academic Purposes. Cambridge: Cambridge University Press.

FOERTSCH, M. 1998. A study of reading practices, instruction, and achievement in District 31 schools [Online]. Available: http://www.ncrel.org/sdrs/areas/liread.pdf [2009, 17 September].

FREY, N. 2006. The research guiding an innovative programme for instruction in reading comprehension. Celebration Press: Good habits, great readers. 1(1):1-14 [Online]. Available:

http://www.pearsonlearning.com/content/File/Good_Habits/web_Research/ghgr_white_ paper.pdf [2009, 16 September].

GOODMAN, KS. 1967. Reading: A psycholinguistic guessing game. Journal of the Reading Specialist, 6:126-135. 
GOODMAN, KS. 1988. The reading process. In Carrell, PL, J Devine \& DE Eskey (Eds), Interactive approaches to second language reading. New York: Cambridge University Press. 11-21.

GRABE, W. 1999. Current developments in second language reading research. TESOL Quarterly 25(3):375-406.

GRABE, W. 2004. Research on teaching reading. Annual review of applied linguistics, 24:4469.

GRABE, W \& LF STOLLER. 2002. Teaching and researching reading. Harlow: Pearson.

GRENFELL, M \& L ERLER. 2007. Language learner strategies. Language Learning Journal, 35(1):5-7.

GRENFELL, M \& V HARRIS. 1999. Modern languages and learning strategies: In theory and practice. London: Routledge.

HARMER, J. 2001. The practice of English language teaching. Essex: Pearson.

HENNING, E, W VAN RENSBURG \& B SMIT. 2004. Finding your way in qualitative research, Pretoria: Van Schaik.

ISENBERG, N. 1990. Literacy competence: The ELT reader and the role of the teacher. ELT Journal, 44(3):181-190.

KARAKAS, M. 2002. The effects of reading activities in ELT trainee teachers' comprehension of short stories. Unpublished MA Thesis. Canakkale: Canakkale Ozsekiz Mart University, Turkey.

KITAO, K \& SK KITAO. 1989. Difficulties Japanese have in reading English. [Online]. Available: http://eric.ed.gov/PDFS/ED278214.pdf [2010, October 20].

KODA, K. 2007. Reading and language learning: Crosslinguistic constraints on second language reading development. Language learning, 57:1-44.

KRINGELBACH, ML, P VUUST, P \& J GEAKE. 2008. The pleasure of reading. Interdisciplinary science review, 33(4):321-355.

LEEDY, PD \& JE ORMROD. 2001. Practical research: Planning and design. New Jersey: Merrill Prentice Hall.

LYE, J. 1993. Contemporary literary theory [Online]. Available: http://www.brocku.ca/english/courses/2P70/contemporary_literary_theory.php [2009, 13 September].

LYE, J. 2003. On the uses of studying literature [Online]. Available: http://www.www.brocku.ca/english/jlye/uses.php [2009, 14 September].

NUTTALL, C. 2000. Teaching reading skills in a foreign language. Oxford: McMillan Heinemann.

MACLEISH, A. 1968. Adapting and composing reading texts. TESOL Quarterly, 2(1):43-50.

PEARSON, PD \& L FIELDING. 1991. Reading for comprehension. In Barr, R, ML Kamil, P Mosenthal \& PD Pearson (Eds), Comprehension instruction: Handbook of Reading Research. Mahwah: Lawrence A. Erlbaum.

RIECKEN, TJ \& MR MILLER. 1990. Introduce children to problem solving and decision making by using children's literature. Social Studies, 81(2):59-64. 
RUBIN, J. 1975. What the 'good language learner' can teach us. TESOL Quarterly, 9:41-51.

RUMELHART, DE. 1977. Towards an interactive model of reading. In Donic, S (Ed), Attention and performance. Hillsdale: Lawrence Erlbaum Associates.

RUMELHART, DE. 1980. Schemata: The building blocks of cognition. In Spiro, RJ, BC Bruce \& WE Brewer. Theoretical issues in reading comprehension. Hillsdale: Lawrence Erlbaum. 33-58.

SMITH, F. 1985. Reading. Cambridge: Cambridge University Press.

STERN, HH. 1975. What can we learn from the good language learner? Canadian Modern Language Review, 31:304-318.

TAKEUCHI, O. 2003. What can we learn from good language learners: A qualitative study in the Japanese foreign language context. System, 31:385-392.

TORELL, O. 2001. Literary competence beyond conventions. Scandinavian Journal of Educational Research, 45(4):369-379.

UR, P. 1996. A course in language teaching. Cambridge: Cambridge University Press.

URQUHART, S \& C WEIR. 1998. Reading in a second language: Process, product and practice. London: Longman.

WALLACE, C. 1986. Learning to read in a multicultural society: the social context of second language literacy. Oxford: Pergamon Press.

WALLACE, C. 2001. Reading. In Carter R \& D Numan [Eds], The Cambridge guide to teaching English to speakers of other languages. Cambridge: Cambridge University Press. 21-27.

WALLACE, C. 2003. Critical reading in language education. New York: Palgrave Macmillan.

WEAVER, C. 2002. Reading process and practice. Portsmouth: Heinemann.

WILSON, M. 1988. Critical Thinking: Repackaging or Revolution? Language Arts, 65(6): 154-165.

WILLIAMS, E \& C MORAN. 1989. Reading in a foreign language at intermediate and advanced levels with particular reference to English. Language Teaching, 22:217-228.

ZENGIER, S \& TMG SHEPHERD. 2003. What is literature really? A corpus-driven study of students' statements. Style, March 22.

\section{BIOGRAPHICAL NOTES}

Mr Tayeb Bouazid is a graduate and postgraduate lecturer in the English Department University Mohamed Boudiaf, Msila, Algeria. He has an MA in psychopedagogy and TEFL, a MEd (with specialisation in Environmental Education (UNISA) and a Teacher Trainer Certificate of Advanced Studies from Lancaster University. Mr Bouazid is a freelance writer for the London School of Journalism. E-mail address: tbouazid@yahoo.fr

*Prof Cheryl le Roux (corresponding author) is professor in education in the School of Education, UNISA. Her current academic and research interests include visual research methodologies and the promotion of critical thinking skills. E-mail address: lrouxcs@unisa.ac.za 